\title{
PECULIARITIES OF THE INTERNATIONAL OUTSOURCING SERVICES: UKRAINIAN PERSPECTIVES
}

\author{
Natalia MASLII ${ }^{\text {, Natalia ZAKHARCHENKO }}{ }^{2}$, Luydmila KOSTOLONOVA ${ }^{3}$ \\ Odessa I.I. Mechnikov National University, Ukraine
}

\begin{abstract}
This article analyses the theoretical foundations of outsourcing and the focus of the outsourcing market in Ukraine. The criteria of assessment for the transfer of business functions to outsourcing are determined and EMEA evaluated according to these criteria. The aim of this work is to study the international outsourcing of services and the implementation of analysis of the characteristics of the process of selecting areas for the transfer of business functions to international outsourcing, and in this context to determine the prospects for Ukrainian companies in this market. Methodology. The study is based on the estimation of the states of the EMEA on the key criteria for transferring business functions to outsourcing. When assessing countries, factors are used, which are important indicators of the economic and political climate in the country, and you need to consider when choosing where to send the direction to outsourcing. The assessment of the countries is conducted on a number of criteria such as: labour cost in the country, the attitude to private property, foreign languages' skills (in the language of the country of the customer), availability of developed infrastructure, government support, and implemented under this context measures of state regulation, etc. Results of the evaluation showed that over the past few years in many countries, there has been rather significant activity aimed at improving the country's attractiveness as an international outsourcers, including in Ukraine, so Ukraine has all the prerequisites to occupy a worthy place in the market players of international outsourcing and thus get all the benefits of scientific and technical development and integration in the innovation sector of the world economy. Practical implications. The research is needed for the classification of countries according to their attractiveness because each customer has their own priorities when choosing a supplier and in order to highlight strengths and weaknesses inherent in a particular country. Also, the study is intended to help potential customers of outsourcing services to identify the most suitable locations for the transfer of business functions to international outsourcing. Value/originality. The findings of the study can provide a better understanding of such a category as international outsourcing and help customers of outsourcing services to conduct their own assessment of the transmission of their business functions to international outsourcers.
\end{abstract}

Key words: outsourcing, international outsourcing, IT outsourcing, Ukrainian PI account, EMEA, evaluation criteria, evaluation.

\section{JEL Classification: F490, M210}

\section{Introduction}

The modern conditions of globalization and internationalization of production and economic activities of market forces and pressure from competitors force many companies-banks, insurance and investment organizations, industrial enterprises to consider outsourcing business processes as one of the important competitiveness forming factors. The concept of "outsourcing" is of the English origin or rather the abbreviation of the English term "outside source using", which means the application of external sources or resources (Suchanek, 2015). Outsourcing allows maximizing the use of the strengths of participants of economic relations, achieving the necessary competitive advantage by allowing each party to carry out those functions in which it mostly succeeds, as well as solving important strategic tasks. By outsourcing, companies are able to obtain a cheaper service non-core activities and high quality of work, highly qualified servicing of the specialized areas. Big businesses get additional savings due to the scale of production.

Today, it is impossible to imagine the development of the world economy and of the enterprises themselves

\footnotetext{
Corresponding author:

${ }^{1}$ Department of Economics and Market Relations Modelling, Odessa I.I. Mechnikov National University.

E-mail: masliy.natalia@gmail.com

${ }^{2}$ Department of Economics and Market Relations Modelling, Odessa I.I. Mechnikov National University.

E-mail: nvzakharchenko777@gmail.com

${ }^{3}$ Department of Economics and Market Relations Modelling, Odessa I.I. Mechnikov National University.

E-mail: ludmiluk333@gmail.com
} 
without the use of outsourcing. Almost any large American or European Corporation does not spend time and money on non-core functions, transferring them to outsource to suppliers from their country or from other countries. This behaviour in the market allows not only reducing costs, achieving a high quality of work performed at the expense of high qualification of employees of the service provider of outsourcing but also freeing up a considerable part of the money and manpower that can be directed at solving complex, strategic problems and to achieve significant competitive advantages. Today we can say that in the future it is those market participants will operate successfully who are now transfer much of the internal processes to outsourcing.

Meanwhile, it should be noted that besides the obvious benefits of outsourcing, it is associated with several risks. These risks may be associated with the choice of service provider, preparation of the contract for outsourcing the implementation of the transactions, and such independent from the customer factors as the degree of support from the government of the country where the planned transfer of business functions to outsourcing, the degree of awareness of this country, the labour pool of the outsourcer, and the level of the qualifications, political and economic stability, etc. Thus, consideration of the development in the context of international outsourcing relationship is very important. This is especially important for determining the prospects of operation of the Ukrainian enterprises in the international market of outsourcing services.

\section{The analysis of recent researches and publications}

The problem of efficiency of the introduction of outsourcing of business processes as one of the competitiveness forming factors lies in that they are fairly little investigated in the literature, are mostly fragmented, and do not provide a general vision of the situation in the world markets. Most of the works are devoted to the study of the introduction of outsourcing at the enterprises of specific industries and of informationpublicity character. Aspects of interaction between companies' outsourcing business processes in foreign literature are considered by such authors as: A. Aksenov, G. Anikin, R. Aalders, J.-L. Bravar, G. van der Heiden, P. Gottschalk, J. Guevara, R. G. Brown, K. Dreyfus, S. Kalendzhyan, N. Carr, L. Cohen, J. Marriott, G. Morgan, G. Nolan, S. Notarpanaro, Austin, X. SollySeter, E. Sparrow, K. Tornblom, F. Racer, K. Halle, X. Huntley, J. Harris, D. V. Cheremisin, A. Young and others. This situation allows, using a scientific approach, summarizing and arranged all the previously obtained results, to do their own research of international outsourcing services.

\section{The main material}

Outsourcing business processes are influenced by the economic situation in the country, just as all other business processes of the company, however, in the context of the economic crisis, the company must continue to carry on business and make a profit. The potential generated by collaboration with suppliers of business services cannot refuse any modern company because of the increase in efficiency caused by the implementation of technological innovations, as well as knowledge and experience of professionals is essential for business success. Today, many companies run their deals for outsourcing not effective enough, not taking into account the changes and challenges, which are in the market. But also many managers that use the services of third-party organizations not just to "patch holes" in the work of their own financial, legal, and other departments but in order to have a serious and profound strategic impact on a business, and such a behaviour is the most relevant in the current crisis conditions.

In connection with the economic crisis, there is an urgent need to reduce costs and new market requirements to the business, the accumulation of activity by turning to it outsourcing and outsourcing business processes and reducing the number of requests to external service providers. The financial component of outsourcing deals is becoming more complex and risky, and it puts additional pressure on those responsible for the decision. Now they have to demonstrate a higher level of professional knowledge in the field of business, especially in terms of compliance with the internal requirements of the various departments, as well as work with external suppliers for outsourced services.

It should be noted that relatively recently in Ukraine, outsourcing began active development. Partly, this activity can be attributed to companies with Western capital, which prefer to focus on core business, shifting processes to outsourcers who have the necessary level of training services for the special systems. In turn, this allows reducing the cost of template operations, improving the efficiency of business processes and to new services in the shortest possible time. However, some percentage of companies with Ukrainian capital still confronts the contractors, believing that outsourcing services unnecessarily expensive, and was entrusted to lead important infrastructure projects to staff members, considering it as a cost centre that provides the infrastructure function, not a source of business benefits.

As evidenced by studies of ANCOR holding on "Evolution of outsourcing. Analysis of the relevance and quality assessment of services", which was conducted in 2016 among managers of foreign and Ukrainian companies operating on the territory of Ukraine, $36 \%$ of respondents noted that their employers outsourced 
business processes including: IT services is $40,5 \%$, logistics - 35,1\%, resource support of production processes - $27 \%$, marketing services at $21.6 \%$, accounting for $13.5 \%$, payroll $13.5 \%$, processing and systematization of information to $8.1 \%$, outsourcing of medical representatives $-8.1 \%$, accounting personnel and HR administration - 5.4\%, and administrative functions $-2.7 \%$. The survey showed that $41.2 \%$ of respondents believe the main advantage of using outsourcing services saving own resources, $37.6 \%$ of respondents said about optimizing and accelerating business processes, $32.9 \%$ believe that their business became more effective, $14.1 \%$ - improvement of the quality and control of work processes, $14.3 \%$ consider that thanks to the outsourcing companies, they are able to use solutions based on the latest achievements of the industry (Kononov, 2016).

For a fuller understanding of the category of outsourcing, there is its classification. The analysis of scientific sources showed that among scientists, there is no single approach to the classification of types of outsourcing (Suchanek, 2015; Horova, 2014) but mostly scientists differentiate between the types of outsourcing according to the nature of the activities transferred to outsourcing. The most appropriate classification according to the author is the classification of Maiorova I. N. by types of activities. She classifies them so: IT outsourcing, manufacturing outsourcing, logistics outsourcing, staff outsourcing, accounting outsourcing (Mayorov, 2010).

In Ukraine as in many other countries, the most widely outsourced is IT technology. This can be explained primarily by the presence in our country of scientific and technological potential and human capital, which has a competitive expertise in this area. So after ten years of appearing on the market, an industry engaged in software development services software IT products, complex solutions for their testing and support, became one of the leading in the country. Not only growth but also on the contribution to the trade balance of the country.

According to UKRINFORM, in recent years the industry of IT outsourcing is growing rapidly - about $40 \%$ a year and if this trend continues, in 10 years, the size of this sector in Ukraine will amount to $\$ 10$ billion, and in this area will work more than 200 thousand representatives [14]. It should be noted that programs developed in Ukraine are used in the information systems of major global banks, the management of Boeing, in the billing systems ofleading communications operators. In Ukraine, there are companies who develop and promote the program under its own brand - GSC World (games "Cossacks", "S.T.A.L.K.E.R."), "Terrasoft" (CRM system), ELEKS Software (information system for medical institutions Doctor Eleks, Eleks), navigation software Autonavigator), "Visicom" (e-map) (UKRINFORM (2010)).
However, Ukraine is now at the end of the list of EMEA (Europe, Middle East, and Africa), where it has overtaken not only the countries of Eastern Europe but also African countries such as Mauritius and Morocco. Thus, according to Gartner's EMEA region in 2016, every twelfth company ordered outsourcing software development in Mauritius. For Ukraine, the number of such requests made 1 to 30 . In order to understand what the constraints are and what are the prospects of Ukrainian companies in the international market of outsourcing services, it is needed to determine the place of our country among the competitors, its strengths, and weaknesses. Also, given the urgent need for cost reduction and improvement in this regard, many customers interest in the services of outsourcing, the author proposed the method of categorizing countries from different regions of the world with the aim of identifying the most attractive locations in terms of transmission destinations for outsourcing.

The assessment of the countries is conducted on a number of criteria such as: cost of labour in the country, the respect for private property, foreign language proficiency (the language of the country of the customer), availability of infrastructure, support from the government and the introduction of measures of state regulation, etc. The goal is not only to classify countries according to their attractiveness because each customer has their own priorities when choosing a supplier but primarily to highlight strengths and weaknesses inherent in that particular country. This study is also intended to help potential customers of outsourcing services to identify the most suitable locations for the transfer of business functions to international outsourcing.

Figure 1 shows the evaluation criteria of the countries for the transfer of business functions to international outsourcing. The basis of this classification lays in the statistical information of Gartner, dedicated to research in the field of IT and telecom (Mironov, 2014).

Support from the government: This criterion shows the extent, to which government institutions and ministries promote their country as an offshore outsourcer. What measures are being taken to support and protect local service providers. It also assesses the willingness of the government to develop and invest in the educational system to acquire skills and knowledge of workers.

Reserves of labour (human capital): Manpower was evaluated on quantitative and qualitative grounds. Applications - project management skills, competence in the field of programming, management of business processes, etc., the number of graduates over the past year is also taken into account. It is necessary to assess the country's ability to provide manpower, as needed by the customers.

Infrastructure: This criterion includes an assessment of operational reliability, quality, and sustainability of infrastructure: electricity, telecommunications, and 


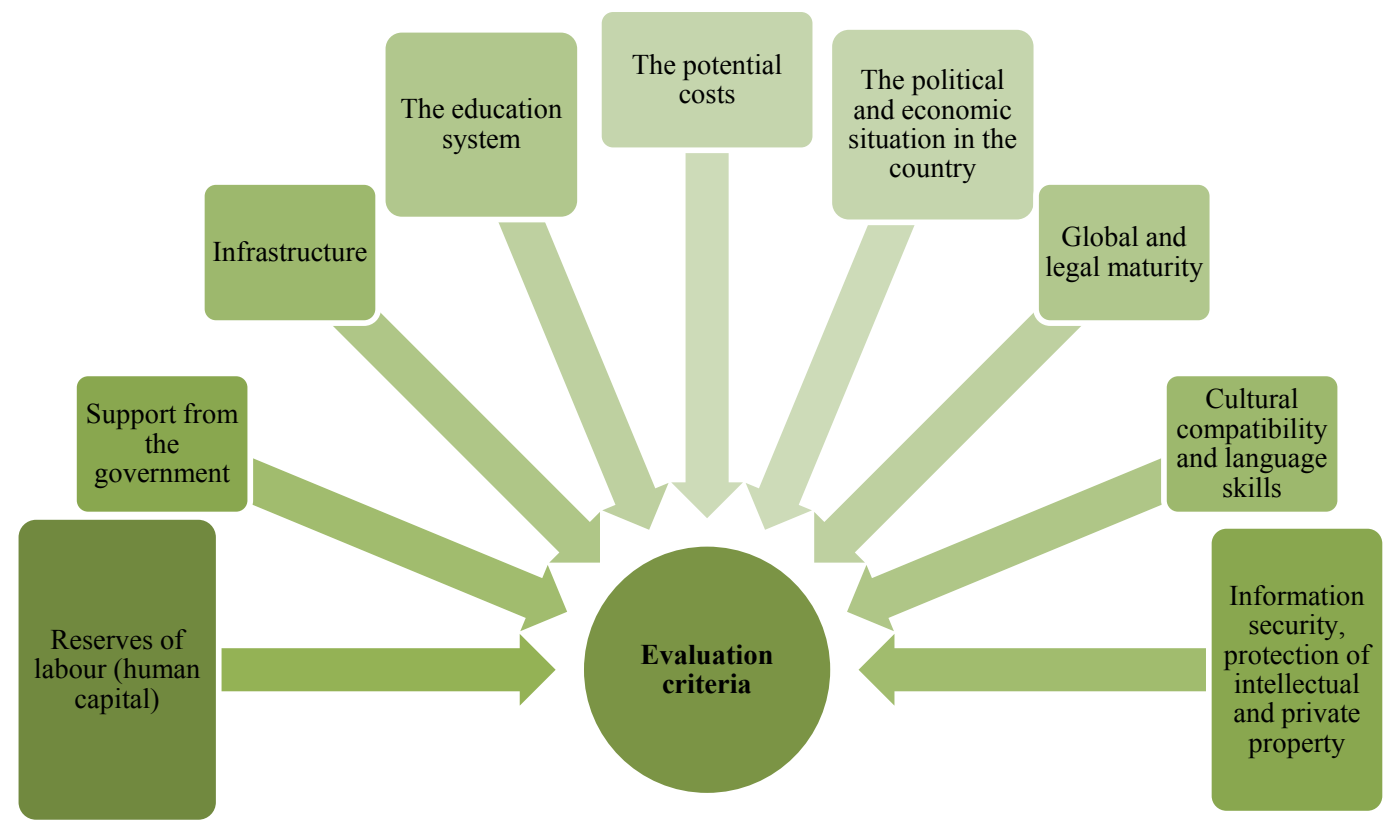

Fig. 1. Criteria for the assessment of the transfer of business functions to outsource

quality of roads, rail services, air, and maritime traffic within and outside the country.

Education system: to assess the quality of the educational system, also the assessment is based on the number of higher education institutions in the country, and the number of graduates who received education in the promising sectors for the last time.

Potential costs: This category assesses the cost of labour in the country, other compensation to employees, as well as the cost of real estate, infrastructure, and telecommunications.

The political and economic situation in the country: the criterion includes political stability, corruption, the level of security; also considers the possibility of international terrorism or wars in the country, the presence of the trade unions, the growth of GDP, and the stability of the national currency.

Global and legal maturity: assesses the presence of international service providers. To assess the degree of legitimacy is from the point of view of compliance with international standards, including overall legislation, tax system, and laws that protect intellectual property. It also assesses the ability of the legal system to protect and support foreign units that operate in the country, and the attitude of intellectual and private property.

Cultural compatibility and language skills: In this case, we assess how cultural differences with the country of the customer may hinder the successful conduct of business. Assess the level of accessibility, including the proximity and accessibility of centres, the ability to quickly get into the country, as well as the difference in time. The assessment also includes oral and written language skills and knowledge of technical and business vocabulary. Evaluated knowledge as English - the primary language of offshore outsourcing, and also German (in Eastern Europe), and Japanese (in Asia Pacific).

Information security, protection of intellectual and private property: Assessed the effectiveness of legislation from the point of view of intellectual property protection, information protection, copyright, brand protection, and patent law.

Conducted by the author of the study, the criteria above are given in Table 1. It showed, in the last few years in many countries has been rather significant activity aimed at improving the country's attractiveness as an international outsourcing (Marriott, I., Karamouzis, F. \& Huntley, H. (2009)). Considered in more detail, the results of the analysis of the region belong to Ukraine Europe, Middle East, and Africa. From this region to the list of thirty leaders, there were 13 countries. This includes countries, which already for a long time are members of the EU, and those who have joined recently, or not included at all. For the first time in 2008, this list includes two North African countries - Morocco and Egypt (Table 1).

The fact that none of the countries of the region have reached a rating above "good" in the category of "government support" reflects the need to undertake a number of measures at the government level for the support of foreign and local suppliers of outsourcing services. This is especially felt in Ukraine. That the state of Ukrainian entrepreneurs is expected not only the solution of fundamental problems of education but also much more: reducing the tax burden, effective laws, and mechanisms of venture investment. At the time the state protectionism has helped the Indian companies to enter into worldleaders in the development of custom software. 
Table 1

Assessment of the state of Europe, the Middle East, and Africa on key criteria for the transfer of business functions in international outsourcing

\begin{tabular}{|c|c|c|c|c|c|c|c|c|c|c|}
\hline \multirow[b]{2}{*}{ Countries } & \multicolumn{10}{|c|}{ Factors } \\
\hline & 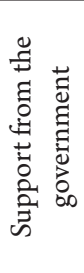 & 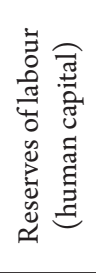 & 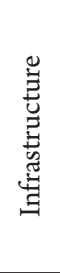 & 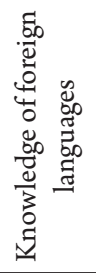 & 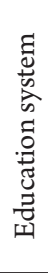 & 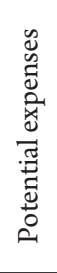 & 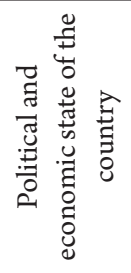 & 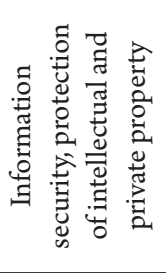 & 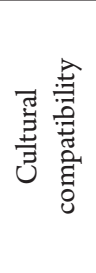 & 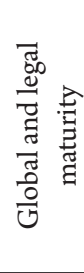 \\
\hline Hungary & 2 & 3 & 3 & 3 & 3 & 3 & 4 & 3 & 4 & 3 \\
\hline Egypt & 3 & 2 & 3 & 3 & 3 & 3 & 2 & 2 & 3 & 2 \\
\hline Israel & 3 & 3 & 4 & 4 & 4 & 2 & 3 & 5 & 4 & 4 \\
\hline Ireland & 4 & 3 & 4 & 5 & 4 & 3 & 5 & 5 & 5 & 5 \\
\hline Spain & 3 & 3 & 4 & 3 & 4 & 3 & 5 & 4 & 4 & 4 \\
\hline Morocco & 3 & 2 & 2 & 3 & 1 & 3 & 2 & 3 & 3 & 2 \\
\hline Poland & 3 & 3 & 2 & 3 & 3 & 3 & 4 & 3 & 4 & 3 \\
\hline Russia & 2 & 3 & 3 & 2 & 4 & 3 & 2 & 2 & 3 & 2 \\
\hline Romania & 3 & 2 & 2 & 3 & 3 & 3 & 3 & 2 & 3 & 2 \\
\hline Slovakia & 2 & 2 & 2 & 3 & 3 & 4 & 4 & 3 & 4 & 3 \\
\hline Ukraine & 2 & 2 & 2 & 2 & 3 & 4 & 1 & 1 & 2 & 2 \\
\hline Czech Republic & 3 & 3 & 3 & 3 & 3 & 3 & 4 & 3 & 4 & 3 \\
\hline South Africa & 2 & 2 & 2 & 5 & 3 & 2 & 2 & 4 & 4 & 3 \\
\hline
\end{tabular}

* The assessment was conducted on a five-point scale, where excellent is 5 points, very good - 4 points, good - 3 points, satisfactory - 2 points, bad - 1 point.

Compiled by the author on the materials (Marriott, I. (2014); Marriott, I. (2005); Marriott, I. (2013))

Ukraine needs to learn from the Indian experience and to initiate the draft law on the adoption of a special tax regime for companies operating in the market of information technologies. Its implementation will help in the short term to increase the amount of "new export industry" significantly. It should be noted that the last few years Ukrainian companies-outsourcing companies such as EPAM, Ciklum, ELEKS, Luxoft, N-iX, Miratech, Intetics, SoftServe very actively communicate with representatives of legislative and executive authorities and this has led to the adoption of a number of bills. It was expected that they will provide more opportunities for the industry, more benefits, but they were taken in a shortened version, and unfortunately are the minimum possible, in order to support the export outsourcing.

Data obtained in the field of human resources point to labour shortages and insufficient level of its quality. In this category, none of the countries received a rating above "good." The development of the economies of Israel, Ireland, and Spain indicates a high level of development of their infrastructure. These same countries and Russia received the highest rating in quality of education. As for Ukraine, it is enough appreciating the level of a basic university or technical education ("good"), it should be noted that universities do not provide in-depth training in the field of information technology, do not prepare analysts or programmers for specialized areas of the information technology market. It shows a rating of "satisfactory" in terms of the labour pool.
On existing problems in infrastructure provision indicates a "satisfactory" assessment. So despite the development of science and technology in Ukraine absolutely there is no connection "idea-product". The country has almost no powerful centres of innovation, which could support the development of advanced industries and services. The removal of these barriers for the outsourcing market development in Ukraine will allow our country to join a huge global industry with a wide range of opportunities for different specializations.

Ukraine showed good results in the area of potential expenditure. However, in the whole region, the level of costs should be assessed on a more regular basis because the level of wages, the value of the property, payment of telecommunication, and other expenses have shown a steady growth in the long term.

Countries such as Ireland, Israel, and South Africa are characterized by a high level of English despite a large number of English-speaking population and the high quality of their education. The level of many other countries in this category had also become quite high in recent years, due to the response to increased needs of buyers in continental Europe. Only that country that has joined the list of leaders of Morocco effectively uses in the business of outsourcing knowledge of French. In Ukraine, the rating on this item is "satisfactory" because our professionals have insufficient knowledge of the English language. 
Among the countries that received lower ratings in the area of the political and economic situation, mainly there are those that are not a part of the EU. However, among the countries-members of EU and also many of those, whose activities must be under constant supervision from the point of view of efficiency and quality of services and compliance with the EU law. The region is characterized by a great cultural diversity, with cultural compatibility, only Ukraine received the lowest rating.

More recently, many countries in the region do not become offshore centres for traditional service providers of outsourcing and major suppliers from India. This is reflected in the category "global and legal maturity", where 8 of the 13 countries were valued very highly. Not many countries (except Ukraine) have a sufficient number of providers that are actively positioning themselves outside of their own country.

As for the category of "protection of intellectual and private property," such factors as the maturity of national economies and membership in the EU allowed a number of countries in the region to obtain a high enough rating. As for Ukraine, in the report "global competitiveness 2015-2016" our country ranks 134th on the protection of the rights of ownership and 120 for the protection of intellectual property rights from 139 countries. Thus, for Ukraine, it is necessary to improve the system of protection of intellectual and private property; it must be DL-ing the presence of a system of forms, methods, and ways of protection of rights.

\section{Conclusions}

Therefore, in modern conditions of strengthening of processes of globalization, international outsourcing reflects the new processes and relationships due to a tendency to geoplanetary interaction and integration. It becomes a way for the international transmission of innovation and the growth of innovative activity of the national and world economy, which in turn leads to improving the quality of human capital of the country, which acts as an outsourcer. It should be noted that Ukraine has all the prerequisites to occupy a worthy place in the market players of international outsourcing and thus get all the benefits of scientific and technological development and integration in the innovative sphere of the world economy. Proposed technique for the classification of countries by the number of signs allows potential customers to facilitate the choice of the country for the purpose of conveying direction for outsourcing. This technique not only classifies countries according to their attractiveness but also allows you in visual form to highlight the strengths and weaknesses inherent in each country. In addition, the developed method allows the service providers of these countries to assess the position of their country or region in the world market of outsourcing services, and calculate your chances of increasing market share in the short and long term.

In our opinion, Ukrainian companies have a good chance to accelerate the solution of two main problems of international outsourcing by combining their efforts, because it will help to formulate and defend a common interest, to inform the public about the success of the industry. But, the development of international outsourcing in Ukraine is hampered by two main obstacles: the underestimation of the potential customers of the possibilities of the country and serious institutional barriers. In public opinion, there is developed a strong belief that the only reason these issues are not within the jurisdiction of the individual companies, they cannot be solved without active government intervention. In world practice, there are precedents when the government action was crucial to start the accelerated development of international outsourcing, however, entrepreneurs should not overestimate its capacities.

\section{References:}

Ukraine is a leader in the export of professionals. [Electronic resource]. Retvitered from: http://news.finance.ua/ $\mathrm{ru} / \sim / 2 / 0 /$ all $/ 2012 / 11 / 19 / 291488$

Mironov, M.G. (2014). Your competitiveness. M.: Alpha Press, 160.

Marriott, I. (2014). 7 Gartner's 30 Leading Locations for Offshore Services, 10.

Marriott, I., Karamouzis, F. \& Huntley, H. (2009). Analysis of Egypt as an offshore services location, 9.

Marriott, I. (2005). Consider Offshore Options Around the Globe, 14.

Marriott, I. (2013). 30 leading locations for offshore services, 9.

Everest Research Institute [Electronic resource]. Retvitered from: http://www.everestresearchinstitute.com

Ukrainian IT Industry to Keep on Growing in 2012-2013 [Electronic resource]. Retvitered from: http://itonews.eu/ ukrainian-itindustry-to-keep-on-growing-in-2012-2013/

Central and Eastern European Outsourcing Association [Electronic resource]. Retvitered from: http://ceeoa.org/ Kononov I. (2016). Demand Analysis and assessment of the quality of outsourcing services in Ukraine. [Electronic resource]. Retvitered from: http://www.chamber.ua

Suchanek, S. A. (2015). Development of outsourcing and its forms: Ukrainian and international aspects [Electronic resource]. Retvitered from: http://ena.lp.edu.ua:8080/bitstream/ntb/33811/1/29-208-215.pdf.

Horova, K. A. (2014). Determination of the main approaches to the classification of outsourcing at the present stage of economic development. Economic analysis : Coll. Sciences. Papers. Ternopil : Publishing - printing center of Ternopil national economic University "Economic thought”,18, 1, 12-19. 
Mayorov, S. N. (2010). Outsourcing in international trade. Theoretical and practical aspects of Economics and intellectual property, 1, 1, 233-239.

UKRINFORM (2010). [Electronic resource]: Official website. - Retvitered from: http://www.ukrinform.ua/ukr/ news/ukraiinskiy_eksport_poslug_it_autsorsingu_shchoroku_zrostae_na_40_1859411

\section{Наталья МАСЛИЙ, Наталья ЗАХАРЧЕНКО, ЛюДМИЛа КОСТОЛОНОВА ОСОБЕННОСТИ МЕЖДУНАРОДНЫХ АУТСОРСИНГОВЫХ УСЛУГ: ПЕРСПЕКТИВЫ ДЛЯ УКРАИНЫ}

Аннотация. В данной статье проанализированы теоретические основы аутсорсинга и особенности рынка аутсорсинга в Украине. Определены критерии оценки стран для передачи бизнес-функций на аутсорсинг и проведена оценка EMEA по этим критериям. Целью работы является исследование международных аутсорсинговых услуг и осуществления анализа особенностей процесса выбора направления для передачи бизнес-функций на международный аутсорсинг и в этом контексте определить перспективы для украинских предприятий на этом рынке. Методика. Исследование основано на оценке государств региона EMEA по ключевым критериям для передачи бизнес-функций на аутсорсинг. При оценке стран были использованы факторы, которые являются важными показателями экономического и политического климата в стране, и которые необходимо учитывать при выборе места для передачи направления на аутсорсинг. Оценка стран проводилась по ряду критериев, таких как: стоимость рабочей силы в стране, отношение к частной собственности, владение иностранными языками (на языке страны заказчика), наличие развитой инфраструктуры, поддержка со стороны правительства и введены в связи с этим меры госрегулирования и т.д. Результаты оценки показали, что в течение последних нескольких лет во многих странах наблюдалась довольно существенная активность, направленная на повышение привлекательности страны в качестве международных аутсорсеров, в том числе и в Украине; таким образом, Украина имеет все предпосылки, чтобы занять достойное место на рынке игроков международного аутсорсинга и за счет этого получить все преимущества научно-технического развития и интеграции в инновационную сферу мировой экономики. Практическое значение. Данное исследование необходимо для квалификации стран по их привлекательности, поскольку у каждого заказчика есть свои приоритеты при выборе поставщика и для того, чтобы выделить сильные и слабые стороны, присущие той или иной стране. Также исследование призвано помочь потенциальным заказчикам услуг аутсорсинга выявить наиболее подходящие места для передачи бизнес-функций на международный аутсорсинг. Значение/оригинальность. Полученные данные исследования способны обеспечить лучшее понимание такой категории как международный аутсорсинг и помогут заказчикам услуг аутсорсинга, проводить собственную оценку мест для передачи своих бизнесфункции на международных аутсорсеров. 